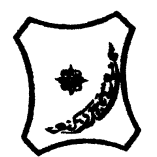

Bayero Journal of Pure and Applied Sciences, 10(1): 66 - 71

Received: November, 2016

Accepted: May, 2017

ISSN $2006-6996$

\title{
EFFECTS OF NITROGEN LEVELS AND HARVEST FERQUENCY ON THE GROWTH AND LEAF QUALITY OF MORINGA (Moringa oleifera Lam) IN SUDAN SAVANNA OF NIGERIA
}

\author{
${ }^{1}$ Adamu, U. A. ${ }^{*},{ }^{1}$ Adamu, I. ${ }^{2}$ Auwalu, B. M., ${ }^{2}$ Bello, T. T., ${ }^{3}$ Gashua, A. G. and ${ }^{4}$ Kurawa, I. \\ A. \\ ${ }^{1}$ Forestry Research Institute of Nigeria, ${ }^{2}$ Department of Agronomy, Bayero University, Kano, ${ }^{3}$ Department of \\ Agronomy, Federal University Gashua Yobe State. ${ }^{4}$ Department of Agric Science, Sa'adatu Rimi College of \\ Education, Kano. \\ * adamubnusmanu96@yahoo.com, +2348066597177
}

\begin{abstract}
Field experiment was conducted under irrigation at teaching and research farm of Faculty of Agriculture, Bayero University Kano, during 2011/2012 dry season to investigate the effects of different nitrogen levels and harvest frequency on growth and leaf quality of Moringa (Moringa oleifera (Lam)). The treatments consisted of four levels of nitrogen $(0,50,100$ and $150 \mathrm{~kg} \mathrm{~N} \mathrm{ha-1})$ and three times of harvest frequency $(2,3$, and 4 weeks). These were arranged in a split plot design with the nitrogen levels allocated to the main plots while the harvest frequency allocated to the sub plots and replicated four times. The data collected were subjected to analysis of variance (ANOVA) using GenStat and significant different means were separated using DMRT. The result shows that application of nitrogen significantly $(P<0.05)$ increase plant height, number of leaflets plant $^{-1}$, plant stem diameter, number of branches plant ${ }^{-1}$, fresh and dry weights plant ${ }^{-1}$. Generally, the growth characters assessed gave maximum value with $150 \mathrm{~kg} \mathrm{~N} \mathrm{ha}^{-1}$ treatment. At first harvest highest protein content of the leaf was also obtained with the higher Nitrogen level (150 kg N ha-1 ), highest Magnesium was obtained with $100 \mathrm{~kg} \mathrm{~N} \mathrm{ha}$ while highest quantity of phosphorus and potassium were obtained with $50 \mathrm{~kg} \mathrm{~N} \mathrm{ha}$. The increase in harvest frequency significantly $(P<0.05)$ increased dry leaf quality of Moringa with the highest protein quality obtained from 4 weeks harvest frequency. Nitrogen and harvest frequency interaction was found to be significant $(P<0.05)$ on dry leaf quality of Moringa.
\end{abstract}

Keywords: Moringa, nitrogen, harvest frequency and leaf quality

\section{INTRODUCTION}

Moringa oleifera is a small tree with sparse foliage often planted in compound and farmlands (Keay, 1989) and belongs to the family Moringaceae. The genus Moringa has about 13 species, and it is native to northern India. It spreads to the tropical and subtropical regions of Asia, Africa and Latin America gaining significant importance throughout the world, which is attributed to its nutritional, medicinal and industrial values (Muhammad, 2008). The tree is found growing in most parts of Nigeria and it is locally referred as Zogale, or Bagaruwar Makka in Hausa, in Fulfulde it is called Kabije, Gawara or Konamarade. The Yorubas call it Ewe ile and the Igbo call it Ikwe Oyibo. Moringa was probably introduced into Nigeria by Arab traders and the plant has several Arabic names Ruwag, Alim, Halim, Shagara Al ruwag (Auwalu, 2009). In many parts of West Africa, Moringa leaves are considered as important leafy vegetables (Auwalu, 2009), which provides both high protein content and quality that meets the estimated amino acid requirement especially for children between the age of 2 - 5 (Kalb and Kuo, 2002).

Leaves of Moringa are the most nutritious part of the plant, and have been used to combat malnutrition especially among infant and nursing mothers. The leaf contains $22-35 \%$ protein together with all essential amino acids. It also contains carbohydrate at varying levels. The protein quality of Moringa leaves rivals that of milk and eggs. Ounce by ounce Moringa leaves contain four times vitamin A and beta-carotene than carrot, four times calcium and two times protein than milk, more iron than spinach, seven times vitamin C than oranges, and three times more potassium than bananas (Fahey, 2005) and more proteins than peas (Kalb and Kou, 2002). Moringa leaf is an excellent source of vitamins, minerals and protein perhaps more than any other tropical vegetable (Anonymous, 2008).

In Nigeria, Moringa is often grown as a live fence or a backyard tree, not much work has been done on the agronomy of the crop (Auwalu, 2009), there is need therefore, to explore the most favorable conditions for cultivating Moringa in order to meet the growing demands by farmers. Moringa growers have to increase their production by adopting appropriate strategies and techniques which will lead to sufficient and sustainable yields without depleting the natural resource base by establishing the best agronomic practices for cultivation and utilization of the crop. Thus, the aim of this research work was to determine the optimum level of Nitrogen required for growing Moringa as vegetable crop and the appropriate harvest frequency for optimum quality of the Moringa leaves. 


\section{MATERIALS AND METHODS}

The experiment was conducted during the 2011/2012 dry season at teaching and research farm of Faculty of Agriculture, Bayero University, Kano (latitude $11^{0}$ $58^{\prime} \mathrm{N}$ and longitude $8^{\circ} 25^{\prime} \mathrm{E}, 457 \mathrm{~m}$ above sea level) in the Sudan Savannah ecological zone of Nigeria. The field had been intensively cropped resulting in degraded soil condition as reflected by the soil physiochemical analysis (Table 1). The treatments combination consisted of four levels of Nitrogen ( 0 , 50,100 and $150 \mathrm{~kg} \mathrm{ha}^{-1}$ ) and three levels of harvest frequency (2, 3 and 4 weeks). The experiment was laid out in a complete randomized block design at initial stage (because at that stage only nitrogen factor was under consideration) but at 12 weeks after sowing (i.e. at harvesting stage) a split plot design was adopted with nitrogen levels at the main plots while harvest frequency, $\mathrm{mm}$ was allocated to the sub plots and replicated four times. The main plot size measured $3 \mathrm{~m} \times 2 \mathrm{~m}\left(6 \mathrm{~m}^{2}\right)$ and was demarcated into three sub plots of $(1 \mathrm{~m} \times 2 \mathrm{~m})$ and each consisted of twenty rows of one meter length. The four inner rows were used as net plots and eight boarder rows were used for sampling purpose. An alley way of $1.5 \mathrm{~m}, 1 \mathrm{~m}$ and $0.5 \mathrm{~m}$ were left between replicate, main plot and sub plots respectively. The land was cleared and harrowed, leveled and prepared into irrigation basins, with irrigation channels provided. Two seeds were sown per hole manually at the depth of $2 \mathrm{~cm}$ which were later thinned to one seedling per stand at two weeks after sowing (2 WAS). Spacing of $20 \mathrm{~cm}$ inter row and $10 \mathrm{~cm}$ intra row was used. Nitrogen fertilizer (urea $46 \% N$ ) was used as source of nitrogen and it was applied at 3 WAS, along the side of the Moringa plant (Palada and Chang, 2003). Weeding was carried out manually by hoe three times at three weeks interval before harvesting. The plants were first harvested at 12 weeks after sowing as suggested by Grubben and Denton (2004). The plants were cut manually with knife at $20 \mathrm{~cm}$ from the ground level to encourage side branching so as to enhances yield of subsequent harvests, and it was after the first harvest that the harvest frequency of 2, 3 and 4 weeks treatments were introduced and lasted for three months. Data were obtained on plant height, stem diameter, number of branches plant ${ }^{-1}$, leaflets number plant $^{-1}$, fresh and dry weight plant ${ }^{-1}$, protein, $\mathrm{Mg}, \mathrm{Ca}$, $\mathrm{Fe}, \mathrm{P}$ and $\mathrm{K}$ contents of the Moringa leaves and the data collected were subjected to analysis of variance (ANOVA) using the general linear model of GenStat. Significant treatment means were separated using DMRT (Duncan, 1955).

\section{RESULTS AND DISCUSSION}

Effects of Nitrogen levels on Vegetative Growth of Moringa during the First 12 Weeks.

The mean plant height, stem diameter and number of branches plant ${ }^{-1}$ increases with time, showing significant $(P<0.05)$ differences from the $4^{\text {th }}$ WAS. The highest nitrogen level (150 kg ha-1) gave the highest increased in plant height, stem diameter and number of branches plant ${ }^{-1}$ followed by $100 \mathrm{~kg} \mathrm{~N} \mathrm{ha}^{-1}$ then $50 \mathrm{~kg} \mathrm{~N} \mathrm{ha}^{-1}$ while the control $\left(0 \mathrm{~kg} \mathrm{~N} \mathrm{ha}^{-1}\right)$ gave the lowest increase in plant height, stem diameter and number of branches plant ${ }^{-1}$ (Table 2). The leaflets number plant ${ }^{-1}$ fresh and dry weight plant $^{-1}$ increases with time in all treatments and were significantly $(P<0.05)$ different from the $4^{\text {th }}$ week onwards. Individual plants with higher level of nitrogen had a higher leaflets number, fresh and dry weight plant $^{-1}$ followed by the medium and lower nitrogen levels respectively, while the lowest number of leaflets, fresh and dry weight plant ${ }^{-1}$ were obtained with the control (Table 3). At $4^{\text {th }}$ WAS only $150 \mathrm{~kg} \mathrm{~N}$ $\mathrm{ha}^{-1}$ recorded significantly $(\mathrm{P}<0.05)$ higher weight plant $^{-1}$ while $100,50 \mathrm{~kg} \mathrm{~N} \mathrm{ha}^{-1}$ and the control were found to be statistically at par, at same period 150 and $100 \mathrm{~kg} \mathrm{~N} \mathrm{ha}^{-1}$ produced plant that were statistically the same in dry weight plant ${ }^{-1}$, followed by 50 and $0 \mathrm{~kg} \mathrm{~N} \mathrm{ha}^{-1}$.

The result of this study showed a significant impact of nitrogen application on the growth characters of Moringa measured at the experimental site. Nitrogen is known to be an essential nutrient necessary for stimulation of rapid vegetative growth because of its importance in photosynthesis and formation of chlorophyll, nucleic acid and amino acid (Samuel, 1980). Therefore, considering the low nutrient status of the soil of the experimental site it is to be expected that application of nitrogen will increase the growth performance of the crop.

Growth characters such as plant height, stem girth, number of leaves plant ${ }^{-1}$ and number of branches plant $^{-1}$ were all found to be significantly $(P<0.05)$ affected by level of nitrogen application this is in line with findings of Oliver (2009) who recorded similar result in which best performing result was obtained with NPK fertilizer (27-7-20) at $32-43 \mathrm{Kg}$ week $^{-1} \mathrm{ha}^{-}$ 1 in Moringa production. Dash and Gupta (2009) were also reported to have obtained significant increase in growth characters of Moringa treated with NPK/Urea $\left(5 \mathrm{~g} \mathrm{pot}^{-1}\right)$ and SSP respectively. The result was also similar to that of Matallawa (2012) who reported significant increase in plant height; stem girth, fresh and dry weight plant ${ }^{-1}$ in Moringa treated with NPK $150 \mathrm{Kg} \mathrm{ha}^{-1}$ and $15 \mathrm{tha}^{-1}$ poultry manure.

Effects of nitrogen levels and harvest frequency on nutritional composition of Moringa leaf

The result showed that $150 \mathrm{Kg} \mathrm{N}$ ha-1 produced leaf with highest protein content that was significantly $(P<0.05)$ higher than 0,50 and $100 \mathrm{~kg} \mathrm{~N} \mathrm{ha}^{-1}$ during first harvest (Table 4), while at last harvest, the different nitrogen levels produced leaf with statistically similar protein content comparable to the control. Harvest frequency of 3 and 4 weeks were statistically at par and produced significantly $(\mathrm{P}<0.05)$ higher protein contents than 2 weeks at same period of first and last harvests (Table 4). The magnesium content of the Moringa leaf during first and last harvests showed that there was significant $(P<0.05)$ difference among the nitrogen levels with $100 \mathrm{~kg} \mathrm{~N}$ $\mathrm{ha}^{-1}$ given the highest magnesium content, followed by 50 and $150 \mathrm{Kg} \mathrm{N} \mathrm{ha}^{-1}$ which were statistically at par but significantly higher than $0 \mathrm{~kg} \mathrm{~N} \mathrm{ha}^{-1}$ but there was no significant effect of harvest frequency on magnesium content (table 4). 
The result presented on table 4 also indicated that 50 $\mathrm{Kg} \mathrm{N} \mathrm{ha}{ }^{-1}$ produced leaf with higher phosphorus and potassium content that was significantly $(P<0.05)$ higher than 150,100 and $0 \mathrm{Kg} \mathrm{N}^{-1}$ which were statistically similar during first and last harvests, while during first harvest 4 weeks harvest frequency produced leaf with significantly $(P<0.05)$ higher phosphorus content than 3 and 2 weeks harvest frequencies statistically at par. But during last harvest 4 and 3 weeks harvest frequencies statistically at par produced leaf with significantly $(P<0.05)$ higher phosphorus content than 2 weeks harvest frequency. At same period of first and last harvests, 2 weeks harvest frequency produced leaf that was significantly $(P<0.05)$ higher in potassium content than 3 and 4 weeks which were statistically similar. There were no significant effects of both nitrogen levels and harvest frequency on the calcium and iron composition of Moringa leaf during first and last harvests.

The study revealed that nitrogen and harvest frequency significantly $(P<0.05)$ affected the quality of Moringa leaf, with increase in the rate of nitrogen application and weeks of harvest frequency high quality leaf was obtained especially with $150 \mathrm{~kg} \mathrm{~N} \mathrm{ha}$ ${ }^{1}$ and 4 weeks harvest frequency similar to what was obtained by Amaglo et al. (2009). The highest protein content obtained agreed with findings of Brady and Weil (1999) who reported that plant responds quickly to increased availability of nitrogen. They also reported that healthy plant foliage generally contains 2.5 to $4.0 \%$ nitrogen, depending on the age of the leaves and weather the plant is legume. Delvin and Witham (2002) reported that, the most recognize role of nitrogen in plant life is its presence in the protein molecule. While the minimum leaf quality was obtained from the control and two weeks harvest frequency. This indicated that there is still need for raising nitrogen level for maximum Moringa leaf production and high quality nutrition's leaf as suggested by Ajouku et al. (2008) and Davis (2000), who suggested $250 \mathrm{~kg} \mathrm{ha}^{-1}$ of compound fertilizer and $280 \mathrm{~kg} \mathrm{~N}$ and $350 \mathrm{~kg} \mathrm{P} \mathrm{ha}^{-1}$ respectively also National Research Council (NRC), (2006), reported that mulching and fertilization improve yield and quality of the Moringa leaf.

\section{Interaction between nitrogen levels and harvest frequency on nutritional composition of Moringa leaf}

Table 5 and 6 shows the interaction between nitrogen levels and harvest frequency on protein and phosphorus content during first and last harvests of the Moringa leaf, the result indicated positive interaction between nitrogen levels and harvest frequency on protein, phosphorus and iron content. The best combination that produced leaf with highest protein content was $150 \mathrm{~kg} \mathrm{~N} \mathrm{ha}^{-1}$ and 4 weeks harvest frequency during first harvest, while at last harvest $100 \mathrm{~kg} \mathrm{~N}$ ha- ${ }^{1}$ and 4 weeks harvest frequency was the best combination. The interaction between nitrogen level of $50 \mathrm{~kg} \mathrm{ha}{ }^{-1}$ and 4 weeks harvest frequency was the combination with highest phosphorus content during the two harvests regime. The highest iron content of the Moringa leaf (Table 7) produced during last harvest was recorded with $0 \mathrm{~kg}$ $\mathrm{N}$ ha $^{-1}$ and 3 weeks harvest frequency combination, but statistically at par with $50 \mathrm{~kg} \mathrm{~N}$ and 3 weeks harvest frequency.

\section{Conclusion}

From the results of the study, it can be concluded that Moringa responded positively to both nitrogen and harvest frequency for better growth and quality of the leaves. All the growth characters and most of nutrient composition of leaves were all found to be affected with an increase in both Nitrogen and harvest frequency. Based on the study, it can be suggested that farmers in the area of study should apply $150 \mathrm{Kg}$ $\mathrm{N}$ ha ${ }^{-1}$ and harvest frequency of 4 weeks after the initial harvest at 12 WAS for better growth and good quality of Moringa leaf.

Table 1; Pre-planting soil characteristics of the experimental site

\begin{tabular}{lll}
\hline Soil Properties & $0-15 \mathrm{~cm}$ & $15-30 \mathrm{~cm}$ \\
\hline Clay & 12 & 8 \\
Sand & 73 & 69 \\
Silt & 15 & 23 \\
Textural Class & Sandy loam & Sandy loam \\
Chemical Properties & & \\
pH in water & 7.10 & 7.05 \\
pH in 0.01m CaCl & 6.60 & 6.30 \\
Organic Carbon $\left(\mathrm{g} \mathrm{kg}^{-1}\right)$ & 6.38 & 5.19 \\
Total Nitrogen $\left(\mathrm{g} \mathrm{kg}^{-1}\right)$ & 0.50 & 0.40 \\
Available P(mg kg & 26 & 22 \\
Exchangeable Bases $\left(\mathrm{mol}^{+} \mathrm{kg}^{-1}\right)$ & & \\
Ca & 4.36 & 4.0 \\
$\mathrm{Mg}$ & 2.10 & 1.73 \\
$\mathrm{~K}$ & 0.27 & 0.29 \\
$\mathrm{Na}$ & 0.09 & 0.08 \\
$\mathrm{CEC}$ & 7.29 & 6.48 \\
\hline
\end{tabular}


BAJOPAS Volume 10 Number 1 June, 2017

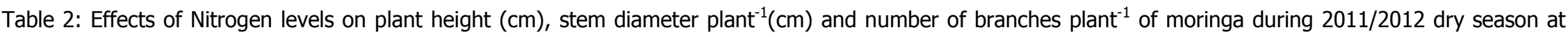
BUK.

\begin{tabular}{|c|c|c|c|c|c|c|c|c|c|}
\hline \multirow[b]{2}{*}{ Treatment } & \multicolumn{3}{|c|}{ Plant height (cm) } & \multicolumn{3}{|c|}{ Stem diameter $(\mathrm{cm})$} & \multicolumn{3}{|c|}{ Number of branches } \\
\hline & 4 WAS & 8 WAS & 12 WAS & 4 WAS & 8 WAS & 12 WAS & 4 WAS & 8 WAS & 12 WAS \\
\hline \multicolumn{10}{|c|}{ Nitrogen $\left(\mathrm{kg} \mathrm{ha}^{-1}\right)$} \\
\hline $\mathbf{0}$ & $8.89 b$ & $16.36 d$ & $42.00 \mathrm{~d}$ & $1.65 c$ & $3.50 \mathrm{~d}$ & $5.90 d$ & $7.75 b$ & $10.50 \mathrm{~d}$ & $14.17 d$ \\
\hline 50 & $9.01 b$ & $37.80 \mathrm{c}$ & $65.50 c$ & $1.75 b c$ & $4.67 c$ & $7.24 c$ & $7.75 b$ & $13.08 \mathrm{c}$ & $16.67 c$ \\
\hline 100 & $9.08 b$ & $44.85 b$ & $86.26 \mathrm{~b}$ & $1.93 a$ & $5.86 \mathrm{~b}$ & $10.86 b$ & 8.67a & $14.50 \mathrm{~b}$ & $18.42 b$ \\
\hline 150 & $9.89 a$ & $53.03 a$ & $105.54 a$ & 1.89ab & $6.98 a$ & $12.15 a$ & $8.50 a$ & $15.25 a$ & $21.33 a$ \\
\hline SE+ & 0.300 & 1.611 & 3.200 & 0.093 & 0.180 & 0.810 & 0.401 & 0.510 & 0.564 \\
\hline
\end{tabular}

Means followed by the same letter(s) are not significantly different at 5\% level of significance using DMRT.

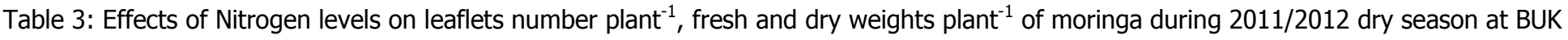

\begin{tabular}{|c|c|c|c|c|c|c|c|c|c|}
\hline \multirow[b]{2}{*}{ Treatment } & \multicolumn{3}{|c|}{ Leaflets number } & \multicolumn{3}{|c|}{ Fresh weight plant $^{-1}$} & \multicolumn{3}{|c|}{ Dry weight plant $^{-1}$} \\
\hline & 4 WAS & 8 WAS & 12 WAS & 4 WAS & 8 WAS & 12 WAS & 4 WAS & 8 WAS & 12 WAS \\
\hline \multicolumn{10}{|c|}{ Nitrogen $\left(\mathrm{kg} \mathrm{ha}^{-1}\right)$} \\
\hline $\mathbf{0}$ & $48.3 c$ & $102.3 d$ & $550.3 d$ & $1.12 b$ & $8.83 d$ & $21.45 d$ & $0.33 b$ & 3.97d & $6.47 d$ \\
\hline 50 & $51.7 \mathrm{bc}$ & $446.8 \mathrm{c}$ & $845.4 c$ & $1.18 \mathrm{~b}$ & $26.08 c$ & $41.95 c$ & $0.36 \mathrm{~b}$ & $7.71 \mathrm{c}$ & $13.32 \mathrm{c}$ \\
\hline 100 & $54.0 \mathrm{~b}$ & $586.7 \mathrm{~b}$ & $1114.3 b$ & $1.12 b$ & $30.05 b$ & $62.34 b$ & $0.44 a$ & $9.19 b$ & $23.11 b$ \\
\hline 150 & $58.3 a$ & $687.2 \mathrm{a}$ & $1159.2 a$ & $1.50 \mathrm{a}$ & $40.98 a$ & $109.28 \mathrm{a}$ & $0.51 a$ & $10.51 a$ & $31.30 a$ \\
\hline SE+ & 3.19 & 38.28 & 91.65 & 0.150 & 1.340 & 6.940 & 0.062 & 0.693 & 5.370 \\
\hline
\end{tabular}

Means followed by the same letter(s) are not significantly different at $5 \%$ level of significance using DMRT 
BAJOPAS Volume 10 Number 1 June, 2017

Table 4: Effects of Nitrogen Levels and Harvest Frequency on Nutritional Composition of Moringa Leaf at BUK 2011/2012 dry season during First and Last Harvest

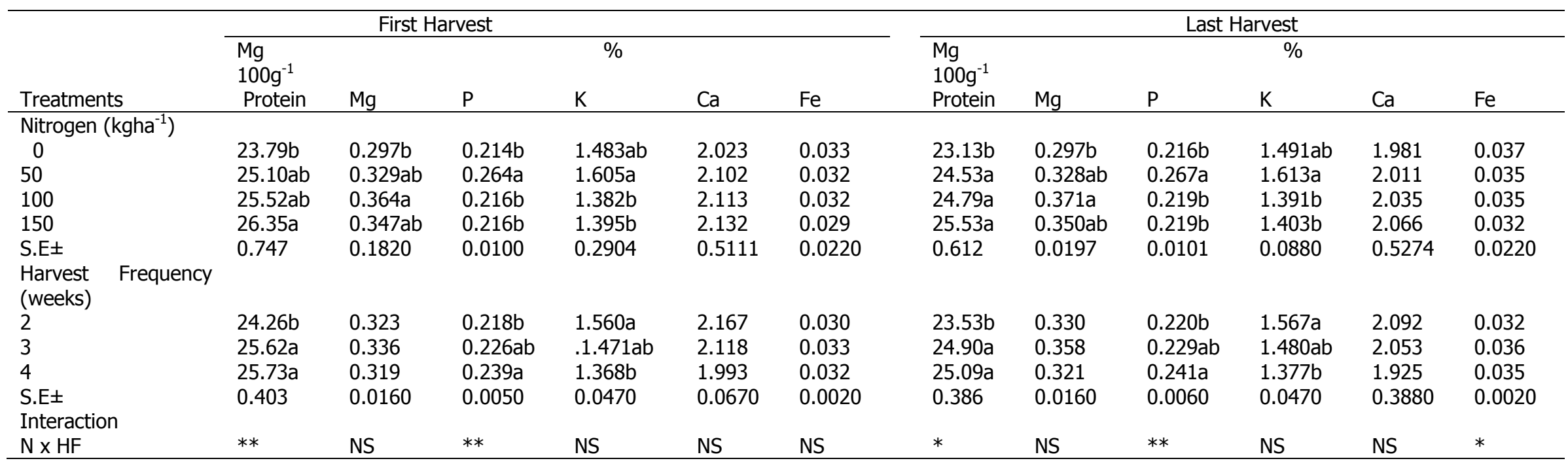

Means followed by the same letter(s) are not significantly different at $5 \%$ level of significance using DMRT. **Significant at $1 \%$, $*$ Significant at $5 \%$, NS Not significant

Table 5: Nitrogen Levels and Harvest Frequency Interaction on Protein and Phosphorus Content of Moringa leaf at BUK during First Harvest

\begin{tabular}{|c|c|c|c|c|c|c|}
\hline \multirow[b]{2}{*}{ Harvest Frequency (Weeks) } & \multicolumn{3}{|c|}{ Protein } & \multicolumn{3}{|c|}{ Phosphorus } \\
\hline & 2 & 3 & 4 & 2 & 3 & 4 \\
\hline \multicolumn{7}{|l|}{ Nitrogen $\left(\mathrm{kg} \mathrm{ha}^{-1}\right)$} \\
\hline 0 & $23.83 b-d$ & $21.62 d$ & $25.93 a b$ & $0.248 b c$ & $0.205 \mathrm{de}$ & $0.188 \mathrm{e}$ \\
\hline 50 & $25.52 a-c$ & $24.44 \mathrm{bc}$ & 26.01ab & 0.204 de & $0.258 b$ & $0.331 a$ \\
\hline 100 & 26.39ab & $26.40 a b$ & $27.83 a$ & 0.210de & $0.215 \mathrm{de}$ & $0.224 \mathrm{~cd}$ \\
\hline 150 & $25.10 \mathrm{bc}$ & $24.57 b c$ & $23.15 \mathrm{~cd}$ & 0.209de & $0.227 b-d$ & $0.213 \mathrm{de}$ \\
\hline SE \pm & & 0.850 & & & 0.012 & \\
\hline
\end{tabular}

Means followed by the same letter(s) are not significantly different at5\% level of significance using DMRT. 
BAJOPAS Volume 10 Number 1 June, 2017

Table 6: Nitrogen Levels and Harvest Frequency Interaction on Protein and Phosphorus Content of Moringa Leaf at BUK during Last Harvest

\begin{tabular}{|c|c|c|c|c|c|c|}
\hline \multirow[b]{2}{*}{ Harvest Frequency (Weeks) } & \multicolumn{3}{|c|}{ Protein } & \multicolumn{3}{|c|}{ Phosphorus } \\
\hline & 2 & 3 & 4 & 2 & 3 & 4 \\
\hline \multicolumn{7}{|l|}{ Nitrogen(kg ha $\left.{ }^{-1}\right)$} \\
\hline 0 & $23.50 \mathrm{~cd}$ & $20.79 \mathrm{e}$ & $25.08 b$ & $0.252 b$ & $0.208 c$ & $0.187 \mathrm{~b}$ \\
\hline 50 & $25.23 b$ & $24.09 c$ & $25.05 b$ & $0.208 c$ & $0.259 b$ & $0.333 a$ \\
\hline 100 & $24.16 c$ & $25.54 b$ & $26.88 a$ & $0.210 \mathrm{c}$ & $0.219 c$ & $0.227 \mathrm{bc}$ \\
\hline 150 & $26.70 a$ & $23.70 \mathrm{~cd}$ & 23.32d & $0.210 \mathrm{c}$ & $0.231 b c$ & $0.217 \mathrm{c}$ \\
\hline SE \pm & & 0.768 & & & 0.011 & \\
\hline
\end{tabular}

Means followed by the same letter(s) are not significantly different at 5\% level of significance using DMRT.

Table 7: Nitrogen Levels and Harvest Frequency Interaction on Iron Content of Moringa Leaf at BUK during Last Harvest

\begin{tabular}{|c|c|c|c|}
\hline HF (Weeks) & 2 & 3 & 4 \\
\hline \multicolumn{4}{|c|}{ Nitrogen $\left(\mathrm{kg} \mathrm{ha}^{-1}\right)$} \\
\hline 0 & $0.036 a b$ & $0.042 a$ & $0.033 a b$ \\
\hline 50 & $0.034 a b$ & $0.029 \mathrm{~b}$ & $0.041 a$ \\
\hline 100 & $0.032 \mathrm{ab}$ & $0.037 a b$ & $0.038 a b$ \\
\hline 150 & $0.028 b$ & $0.038 a b$ & $0.028 b$ \\
\hline SE \pm & & 0.003 & \\
\hline
\end{tabular}

Means followed by the same letter(s) are not significantly different at 5\% level of significance using DMRT.

\section{REFERENCES}

Ajouku, K. B., Ettu, O. and Obasi, T. C. (2008). Moringa oleifera as a Local Plant Resources for Achieving the Millennium Development Goals (MDGs). Raw Materials Research and Development Council (RMRDC). Proceedings of the sensitization workshop and exhibition on socio economic uses of moringa.

Amaglo ,N. K., Timpo, G. M., Ellis, W. O. and Bennette R. N. (2006). Effect of Spacing and Harvest Frequency on the Growth and Leaf Yield

Moringa (Moringa oleifera Lam), a Leafy Vegetable Crop. (anglophone group). Kwame Nkrumah University of Science and Technology Accra, Ghana, November.16-18. http://www.moringafarm.com

Anonymous, (2008). Moringa. Retrieved on $15^{\text {th }}$ February

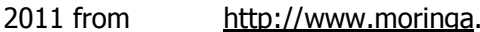
comjournals.org/AJB.

Auwalu, B .M. (2009). Agronomic Management Practices for Commercial Production of Moringa (Moringa oleifera Lam). Unpublished Paper Presented at Two-day Workshop on Sustainable Production and Commercialization of Moringa at Imam Wali Hall Kano Nigeria.

Brady N.C. and Weil R.R. (1999). The Nature and Properties of Soils $12^{\text {th }}$ Edition. Prentice Hall. Upper Saddle River New Jersey pp. 881.

Dash S, and Gupta N. (2009). Effect of inorganic, organic and Biofertilizers on growth of hybrid Moringa oleifera (pkm) .Acad. Journal .plant science 2(3); 220221. ISN 1995-8586 IDOS. Publishers.

Davis, K. (2000). The Moringa Tree Retrieved on $13^{\text {th }}$ May, 2010. From http:// www.echonet.org/

Delvin R.M and Witham F. H. (2002).Plant Physiology $4^{\text {th }}$ edition. CBS publishers and distributors Darya Ganji. New Delhi pp.577

Duncan, D.B. (1955): Multiple Range and Multiple F-Test Biometrics 11:1-42

Fahey, J.W. (2005).Moringa oleifera. A Review of the Medical Evidence for its Nutritional Therapeutic Prophylactic Properties. Part 1. Trees for Life Journal 1:5 pp54-67.
Genstat (2011). Release 10.3DE. VSN. International, 5. The Waterhouse Street, Hemel Heampstead, Heartfordshire HPI IES UK.

Grubben, G.J.H. and Denton, O.A. (2004). Plant Resources of Tropical Africa 2. Vegetables. PROTA Foundation Wageningen, Netherlands/Bachuys Publishers, Leiden, Netherlands/CTA, Wageningen, Netherlands. 668pp.

Kalb, T. and Kuo, G. ( 2002). AVRDC report (2001). Asian Vegetables Research and Development Centre, Shanhua, Tainan, Taiwan. Vii + 155pp. AVRDC. Publication 02-542.

Keay, R. W. J. (1989). An outline Of Nigerian vegetation, $3^{\text {rd. }}$.pp 22-30. Federal Government Printers, Lagos Nigeria.

Matallawa, D.M. (2012) Effects of Manure and NPK Fertilizer on Growth and Leaf Yield of Moringa (Moringa oleifera Lam) in the Sudan Savannah of Nigeria. M.Sc. Dissertation submitted to Department Agronomy BUK. Pp 65-102.

Muhammad, H. (2008). The Blessing Call Zogale: Moringa Tree Prevent 300 Diseases. Daily Trust Newspaper Nigeria, $17^{\text {th }}$ June http://www.dailytrust.com

N R C (2006). Lost crops of Africa. Volume II vegetable. The National Academic Press. Washington, D. C.

Olivier, C. (2009) Intensive Moringa oleifera Caltivation In the North Senigal. Retrieved on $3^{\text {rd }}$ February, 2010 from www.syfia.com/fr/artcle

Palada, M.C. and Chang, L.C. (2003). Suggested Cultural Practices for Moringa International Cooperation Guide. Asian Vegetable Research and Development Centre. Publication No. 03-545-5pp.

Peace Corps (2009). Publication. Moringa :Cultivation and Usage Pocket Guide. Corp de la paix American Almadies lot N/1 TF 23231 BP 2534, Dakar, Senegal.

Samuel, R. A. (1980). Nitrogen Illinois. Agricultural Experiment Station. USA. Pp 452- 455. 